\title{
Identification of Bottlenecks Perceived among the Farmer Producer Organizations to Augment its Role and Function
}

\author{
N. Kathiravan ${ }^{1 *}$, T. Senthilkumar ${ }^{2}$ and N.K. Sudeep Kumar ${ }^{2}$ \\ ${ }^{1}$ Department of Veterinary and Animal Husbandry Extension, Madras Veterinary College, \\ Chennai-600 007, Tamil Nadu, India \\ ${ }^{2}$ Directorate of Extension Education, Tamil Nadu Veterinary and Animal Sciences University, \\ Chennai - 600 051, Tamil Nadu, India \\ *Corresponding author
}

\begin{tabular}{|c|c|}
\hline \multicolumn{2}{|c|}{ A B S T R A C T } \\
\hline & \multirow{8}{*}{$\begin{array}{l}\text { Agriculture is the main occupation of the vast majority of the population and various types } \\
\text { of agricultural products are produced in India and the marketing of all these products is a } \\
\text { complex process. Farmers do not have access to direct market and are selling their produce } \\
\text { to the intermediaries. Because of intermediaries their profit margin is reduced and their } \\
\text { farming business becomes a non-viable one. Improvement in the status of the farmer is } \\
\text { possible only through diversification and commercialization of their agricultural activities. } \\
\text { Producers companies can help small holder farmers participate in emerging high- value } \\
\text { markets, such as the export market and the unfolding modern retail sector in India. Farmer } \\
\text { producer organization (FPO) strengthens support service for small farmers by developing } \\
\text { link between farmers and purchases of agriculture producer. The study was conducted } \\
\text { among four existing FPOs with } 45 \text { respondents in Namakkal district of Tamil Nadu. Data } \\
\text { were collected through well-structured interview schedule among the respondents of four } \\
\text { farmer Producers organizations. The data were analyzed through Garratt ranking technique } \\
\text { and the bottlenecks were ranked under organizational, socio - political, economic } \\
\text { constraints and other constraints. The constraint, lack of co-ordination for different group } \\
\text { activities (97.37) was ranked 'first' and the non - availability of literature on FPO } \\
\text { activities was ranked last with an average mean score of (42.19) by the respondents. }\end{array}$} \\
\hline Keywords & \\
\hline & \\
\hline $\begin{array}{l}\text { organızation, Bottle } \\
\text { necks, Garratt } \\
\text { ranking, }\end{array}$ & \\
\hline Constraints. & \\
\hline Article Info & \\
\hline $\begin{array}{l}\text { Accepted: } \\
\text { 04 July } 2017 \\
\text { Available Online: } \\
\text { 10 September } 2017\end{array}$ & \\
\hline & \\
\hline
\end{tabular}

\section{Introduction}

Agriculture is the main occupation of the vast majority of the population of India. Improvement in the status of the farmer is possible only through diversification and commercialization of their agricultural activities. This is possible only through implementation of agricultural policy reforms, introducing sustainable agricultural practices, optimizing input efficiency, bringing about institutional change, developing human resources capital and through participation of the non-governmental sector in agriculture. There is a need to strengthen support services for small farmers by developing link between farmers and purchasers of agricultural produce. Currently such type of linkages are either not exist or very weak. It is well recognized that the commercialization of small-scale, resource-poor farmers is closely linked to higher productivity, greater 
specialization and higher income (Bernard and Spielman, 2009).

We can mobilize farmers in groups and build their associations called as Farmer Producer Organization (FPOs) to plan and implement product specific cluster/ commercial crop cycles. FPO is a means to bring together the small and marginal farmers and other small producers to build their own business enterprise that will be managed by professionals. FPO can help farmers for production of various agricultural produce as well as during the process of marketing the crops. Farmer organizations offer small farmers to participate in the market more effectively and collectively, they are in a better position to reduce transaction costs of accessing inputs and outputs, obtaining the necessary market information, securing access to new technologies and to tap into high value markets, allowing them to compete with larger farmers and agribusinesses (Stockbridge et al., 2003). The study is therefore proposed to identify the bottlenecks perceived by the respondents of Farmer Producer Organizations (FPO) in improving the livelihood of farming community by collecting information from the existing FPOs members.

\section{Materials and Methods}

The study was purposively conducted at Namakkal district of Tamil Nadu in order to identify the role of farmer producer organisations in improving the livelihood of farming community. In India, Krishi Vigyan Kendras (KVKs) are playing a contributing role in forming, organising and supporting such type farmer producer organizations. At present, there are three Krishi Vigyan Kendras (KVKs) functioning under the administrative control of Tamil Nadu Veterinary and Animal Sciences University. Among these KVKs, the KVK functioning at
Namakkal is liaising with maximum FPOs than the other KVKs. A sample size of 45 respondents was selected randomly from among four FPOs functioning at Chinnamalini, Ponmalai, Aandalurgate and Karanodai villages of Namakkal district. Interview method was selected as an appropriate tool for data collection. An interview schedule incorporating all the variables pertaining to the objective was developed and data were collected through personal interview with the selected respondents. The data collected were coded, tabulated and ranked by Garratt ranking technique and results interpreted.

\section{Results and Discussion}

Bottlenecks encountered by the members of FPO were grouped under four major headings viz., organizational, socio- political, economic and other constraints. The FPO members were asked to indicate the constraints faced by them under a five point continuum ranging from 'least important' to 'very important' with a score of 5,4,3,2 and 1 respectively.

The overall constraints perceived by the members of FPO were analyzed by Garrett ranking technique, which ranged from 'very important' to 'least important' constraint. Based on the value, the constraints perceived by the respondents were ranked and presented in table 1 .

Table 1 showed the details of mean score and rank given by the respondents. It is evident from the study that, lack of co-ordination for different group activities ranked 'first' with an average mean score of 97.37 followed by ineffective linkage (96.37), inefficient monitoring (77.37), predominance of part time farmers (61.82), labour dispute (54.59), Sub - group formed execution (53.17), labour demand at peak section (52.17), non availability of timely credits (51.22), political 
affiliation of member (50.77), in adequate profit to individual members (48.17), non representation of all section in the area
(47.37), low price for produces (45.42), non inclusion of local leaders in FPO (45.27).

Table.1 Bottlenecks perceived by respondents

\begin{tabular}{|c|c|c|c|}
\hline \multirow[t]{2}{*}{ S. No. } & \multirow[t]{2}{*}{ Constraints } & \multicolumn{2}{|c|}{ Garrett ranking technique } \\
\hline & & Mean score & Rank \\
\hline \multicolumn{4}{|c|}{ A. Organizational constraints } \\
\hline 1. & Non - inclusion of local leaders in FPO & 45.27 & XIII \\
\hline 2. & Non - availability of literature on FPO activities & 42.19 & XIV \\
\hline 3. & Lack of co-ordination for different group activities & 97.37 & I \\
\hline 4. & Ineffective linkage & 96.37 & II \\
\hline 5. & Inefficient monitoring & 77.37 & III \\
\hline 6. & Predominance of part time farmers & 61.82 & IV \\
\hline \multicolumn{4}{|c|}{ B. Socio-political constraints } \\
\hline 7. & Political affiliation of member & 50.77 & IX \\
\hline 8. & Sub - group formed execution & 53.17 & VI \\
\hline 9. & Non - representation of all section in the area & 47.37 & XI \\
\hline \multicolumn{4}{|c|}{ C. Economic constraints } \\
\hline 10. & Low price for produces & 45.42 & XII \\
\hline 11. & Non - availability of timely credits & 51.22 & VIII \\
\hline 12. & In adequate profit to individual members & 48.17 & $\mathrm{X}$ \\
\hline \multicolumn{4}{|c|}{ D. Other constraints } \\
\hline 13. & Labour demand at peak section & 52.17 & VII \\
\hline 14. & Labour dispute & 54.59 & $\mathrm{~V}$ \\
\hline
\end{tabular}

The non - availability of literature on FPO activities was ranked last with an average mean score of 42.19. The study showed that, the lack of coordination for different group activities was ranked as 'first' as an important constraint than the other constraints. The reason might be less interaction and less periodical group meetings between the existing sub-groups under each farmer producer organization.

Majority of the respondents are small to marginal land holding farmers and mainly involved in agriculture with ruminants and poultry farming activities. The most important bottlenecks perceived by the respondents are lack of co-ordination for different group activities, ineffective linkage, inefficient monitoring which were revealed under organizational constraints. But the success of these farmer producer organizations is very much depends on the commitment of the members. The integrity and quality leadership as well as suitable market environment are the most important factors for the successful growth of such organizations.

\section{References}

Anonymous, 2013. Policy and Process Guidelines for Farmer Producer Organizations, Department of Agriculture and Cooperation, Ministry of Agriculture, Government of India.

Anonymous, 2014. Krishi Sutra. 2 Success stories of Farmer Producer 
Organization, Small Farmers Agribusiness consortium, Department of Agriculture and Cooperation, Govt. Of India, New Delhi.

Bernard, T., and David J Spielman. 2009. Reaching the rural poor through rural producer organizations: A study of agricultural marketing cooperatives in Ethiopia, Food Policy. 34:60-69

SFAC, 2014. "Detailed List of Farmer Producer Organizations (FPOs State wise)", Small Farmers' Agribusiness Consortium, Department of Agriculture and Cooperation, Ministry of
Agriculture, Government of India, Viewed on 13 Nov 2014 (http:// sfacindia.com/List-of-FPO-Statewise. html)

Stockbridge, M. A., Dorward, and J. Kydd. 2003. Farmer Organizations for Market Access: Learning from Success. Briefing Paper. Wye College, University of London, UK.

Trebbin, A., and M. Hassler. 2012. Farmers' producer companies in India: a new concept for collective action. Environment and Planning A, 44(2), 411-427.

\section{How to cite this article:}

Kathiravan, N., T. Senthilkumar and Sudeep Kumar, N.K. 2017. Identification of Bottlenecks Perceived among the Farmer Producer Organizations to Augment its Role and Function. Int.J.Curr.Microbiol.App.Sci. 6(9): 216-219. doi: https://doi.org/10.20546/ijcmas.2017.609.029 